\title{
Reduction of ripening time of full scale manganese removal filters with manganese oxide-coated media
}

Short title: Reduction of ripening time of Mn removal filters with Mn oxide-coated media

\author{
Jantinus H. Bruins ${ }^{1,2,3}$, Branislav Petrusevski ${ }^{2}$, Yness M. Slokar ${ }^{2}$, Koen Huysman ${ }^{4}$, \\ Koen Joris ${ }^{4}$, Joop C. Kruithof ${ }^{2,5}$, Maria D. Kennedy ${ }^{2,3}$
}

${ }^{1}$ WLN-Technology (email: j.bruins@ wln.nl), Rijksstraatweg 85, 9756 AD Glimmen, The Netherlands

${ }^{2}$ UNESCO-IHE Institute for Water Education, Westvest 7, 2611 AX Delft, The Netherlands

${ }^{3}$ Technical University Delft, Stevinweg 1, 2628 CN Delft, The Netherlands

${ }^{4}$ Pidpa, Department of Process Technology and Water Quality, Desguinlei 246, 2018 Antwerp, Belgium

${ }^{5}$ Wetsus, Centre of Excellence for Sustainable Water Technology, P.O. Box 1113, 8900 CC, Leeuwarden, The Netherlands

\begin{abstract}
Effective manganese removal by conventional aeration-filtration with virgin filter media requires a long ripening time. The aim of this study was to assess the potential of manganese oxide-coated media to shorten the ripening time of filters with virgin media, under practical conditions. A full scale filter filled with virgin sand and a full scale filter filled with anthracite/sand were operated at two groundwater treatment plants, in parallel with (full scale) test filters, with an additional layer of Manganese Oxide-Coated Sand (MOCS) or Manganese OxideCoated Anthracite (MOCA). Significantly different ripening times were observed to achieve an effective manganese removal: 55 days for a filter with virgin sand and 16 days for a filter with virgin anthracite/sand, respectively. The observed differences could be attributed to different feed water quality, different iron loading, and backwashing intensity and frequency. In batch experiments fresh MOCA and MOCS showed good
\end{abstract}


manganese adsorptive properties. Addition of a shallow layer of fresh MOCA in test filters eliminated the ripening time, while a layer of aged MOCS did not significantly shorten the ripening period. The poor performance of the aged MOCS was likely caused by changed properties of aged and dried MOCS, that had lost its adsorption capacity, the auto-catalytic activity and the biological activity.

Key words | filter media, filter ripening, groundwater treatment, manganese oxide coating, manganese removal

\section{INTRODUCTION}

Worldwide, groundwater is the predominant source for drinking water production (United Nations Environment Programme [UNEP] 2008). In addition to naturally occurring compounds, such as $\mathrm{Fe}^{2+}$, $\mathrm{NH}_{4}{ }^{+}, \mathrm{CH}_{4}$, etc., groundwater frequently contains dissolved manganese in excess of drinking water standards (Katsoyiannis et al. 2008), which should be removed for both health and aesthetic reasons. In some countries (e.g., the US, and Central and Eastern Europe) an efficient manganese removal is commonly achieved by pre-oxidation with strong oxidants, such as $\mathrm{O}_{3}, \mathrm{Cl}_{2}, \mathrm{ClO}_{2}, \mathrm{KMnO}_{4}$, followed by rapid sand filtration. Use of strong oxidants for manganese removal is not desirable due to the potential formation of harmful oxidation by-products, as well as costs and risks associated with the usage and handling of chemicals. In some cases pre-oxidation is combined with filtration through a filter bed with a manganese adsorbent, most frequently manganese green sand. This treatment can be very effective but it requires continuous or intermittent regeneration typically with potassium permanganate (Knocke et al. 1991). In view of the above mentioned disadvantages, the removal of manganese from groundwater in The Netherlands and Belgium is commonly achieved with conventional aeration-filtration treatment, also called contact filtration. Under common groundwater conditions (e.g., low $\mathrm{pH})$, manganese removal may be initiated by bacterial activity during aerationfiltration (Diem \& Stumm 1984; Burger et al. 2008). Aeration-filtration is efficient and cost effective, but in practice it is frequently associated with a number of drawbacks such as: 
- very long ripening times of virgin filter media; several weeks to more than a year (Fig. A1, Annex A) are required to achieve an efficient manganese removal (Cools 2010; Krull 2010);

- occasional manganese breakthrough of filters may occur after some years of operation, requiring filter media replacement, associated with additional costs for filter media disposal and replacement (Buamah et al. 2009a).

Ripening of filter media (for manganese removal), is defined as the development of properties to autocatalytically adsorb and subsequently oxidise $\mathrm{Mn}^{2+}$, without the use of strong oxidants, such as $\mathrm{Cl}_{2}, \mathrm{O}_{3}$ and $\mathrm{KMnO}_{4}$.

From Fig. A1 (Annex A), it can be seen that efficient manganese removal in a filter with virgin sand was not achieved until after almost one year of continuous filter operation. However, such a long ripening time is exceptional, typically it takes 1 to 4 months to achieve an efficient manganese removal.

Many authors (Hu et al. 2004a; Kim \& Jung 2008; Kim et al. 2009) describe the potential of Manganese Oxide-Coated Sand (MOCS) to adsorb dissolved manganese from (ground)water. It was also reported that removal of $\mathrm{Mn}^{2+}$ in filters with anthracite is enhanced by development of 'catalytic oxide layers' on aged anthracite, due to formation of Manganese Oxide-Coated Anthracite (MOCA) (Sahabi et al. 2009). Buamah et al. (2008) suggested that the performance of conventional manganese removal plants could be improved by introducing manganese and/or iron (hydro)oxide-rich filter media into rapid sand filters.

The primary aim of the study reported in this paper was to examine if the long ripening time typically required to achieve an effective manganese removal with virgin filter media, in full scale conventional aeration-filtration treatment plants, could be substantially reduced by addition of a MOCS or MOCA layer. 


\section{MATERIALS AND METHODS}

\section{MOCS and MOCA}

The manganese oxide-coated filter media used in this research were obtained from two full scale groundwater treatment plants (GWTPs). MOCS was obtained from GWTP De Punt (Water Supply Company Groningen, The Netherlands), and MOCA was obtained from GWTP Grobbendonk (Pidpa water supply company, Belgium). It was shown that both MOCS and MOCA coatings contain a Birnessite type of manganese oxide (Bruins et al. 2014).

For all batch adsorption experiments and full scale filter experiments fresh MOCA or MOCS were taken directly from an operating, ripened full scale manganese removal filter. However, MOCS was stored in the open air for several months prior to the full scale filter experiments.

\section{Physical and chemical properties of MOCS and MOCA}

Chemical composition of the MOCS and MOCA coating was determined by boiling the media in $3 \mathrm{M}$ $\mathrm{HNO}_{3}$, followed by analysis for $\mathrm{Fe}, \mathrm{Mn}, \mathrm{Ca}$, Si and $\mathrm{Al}$ with inductively coupled plasma mass spectrometry (ICP-MS) according to NEN-EN-ISO 17294-2 (NEN 2004).

The $\mathrm{pH}$ of point of zero charge $\left(\mathrm{pH}_{P Z C}\right)$, i.e., the surface charge of coated filter media depending on structural deficits, unbalanced bonds and the presence of protons, was determined by a mass titration method (Fiol \& Vilaescusa 2009).

\section{Batch adsorption experiments}

To determine the MOCS and MOCA manganese adsorption capacity, batch adsorption isotherm experiments were carried out. Model water used in these experiments contained $1 \mathrm{mmol} / \mathrm{L} \mathrm{HCO}_{3}{ }^{-}$and $2 \mathrm{mg} / \mathrm{L} \mathrm{Mn}^{2+}$ in demineralised water; the $\mathrm{pH}$ was adjusted to 7 with $0.1 \mathrm{M} \mathrm{HCl}$. The bottles containing model water and five different concentrations of either MOCS or MOCA in granular form were agitated on an Innova 2100 shaker at $100 \mathrm{rpm}$ for $48 \mathrm{~h}$. Prior to measuring the final concentration of manganese, the samples were filtered through a $0.45 \mu \mathrm{m}$ membrane filter, and acidified to preserve 
them for the analyses. The manganese concentration was measured, and results were plotted as a Freundlich adsorption isotherm.

The results obtained from the batch adsorption experiments of the two manganese-coated filter media were compared with those obtained with a commercial manganese adsorbent Aquamandix (Aquatechniek, The Netherlands).

\section{Full scale filter runs}

Full scale filter runs were conducted at GWTPs where the manganese-coated filter media were obtained. In total, six different combinations of filter media were used (Fig. 1). Two filters were operated at GWTP De Punt (Fig. $1^{\mathrm{A}-\mathrm{B}}$ ), and the other four (Fig. $1^{\mathrm{C}-\mathrm{F}}$ ) at GWTP Grobbendonk.
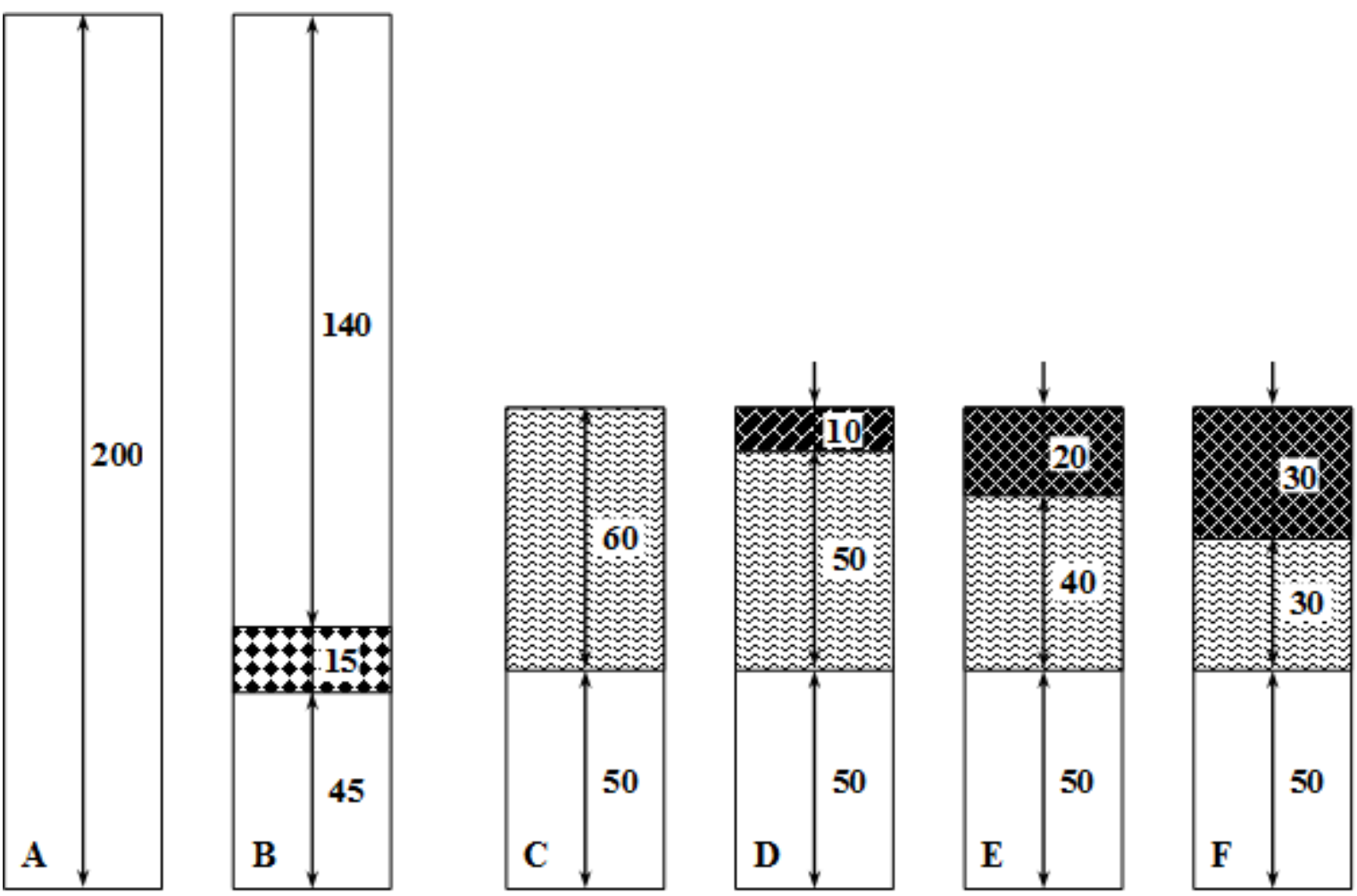

\section{virgin sand}

MOCS

四 virgin anthracite

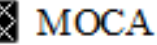

Figure 1: Schematic presentation of filter media layers in the six full scale filters included in the study (all values in $\mathrm{cm}$ ). 
Of the two filters at GWTP De Punt, one filter (Fig. $1^{\mathrm{A}}$ ) was filled with virgin quartz sand, commonly applied at this plant. This filter served as a reference filter. The second filter (Fig. $1^{\mathrm{B}}$ ) was filled with the same virgin sand, however, a $15 \mathrm{~cm}$ layer of sand was replaced by MOCS. The MOCS was aged and dried prior to use in the full scale filter run. Based on practical experience, the MOCS layer was placed at the level where manganese removal in ripened filters is observed at this facility.

The effect of the MOCA layer on the ripening of virgin filter media was studied at GWTP Grobbendonk. This plant utilises filters with dual media - anthracite and sand - which is how the reference filter was prepared (Fig. $1^{\mathrm{C}}$ ). In the other three (full scale) test filters (Fig. $1^{\mathrm{D}-\mathrm{F}}$ ), part of the top anthracite layer was replaced by 10,20 and $30 \mathrm{~cm}$ MOCA respectively. MOCA was placed on the top of the anthracite layer, because at this level manganese removal is observed at this water treatment plant.

The composition of the feed water for the full scale experiments at the two GWTPs is given in Table A1 (Annex A). At GWTP De Punt, groundwater was aerated prior to the test filters. At GWTP Grobbendonk the treatment consists of a $1^{\text {st }}$ stage rapid sand filtration (aeration and biological adsorptive iron removal), a $\mathrm{pH}$ correction with milk of lime and $2^{\text {nd }}$ stage dual media filtration. The feed water for the experiments at GWTP Grobbendonk was the water after $\mathrm{pH}$ correction.

From Table A1 (Annex A) it is evident that the feed water quality at the two test locations differed significantly. In particular the difference in water quality parameters that are known to influence manganese removal $\left(\mathrm{Fe}^{2+}, \mathrm{NH}_{4}{ }^{+}\right.$concentrations, $\mathrm{pH}$ and redox potential) should be noted (Bruins et al. 2013).

Table A2 (Annex A) depicts an overview of process design parameters and operational conditions applied during the test filter runs at both locations. From this table it is evident that especially 'Iron loading per filter run' is substantially different (De Punt: $2.5 \mathrm{~kg} \mathrm{Fe} / \mathrm{m}^{2}$.FR and Grobbendonk: $<0.1 \mathrm{~kg}$ 
$\mathrm{Fe} / \mathrm{m}^{2}$.FR). Iron loading is known to influence manganese removal (Bruins et al. 2013). In Table A3 (Annex A) backwash procedures at both GWTPs are listed.

\section{RESULTS AND DISCUSSION}

\section{Ripening of virgin filter media in reference filters}

In Fig. 2 the ripening times of the two full scale reference filters filled with virgin sand (GWTP De Punt) and anthracite/sand (GWTP Grobbendonk) are shown.

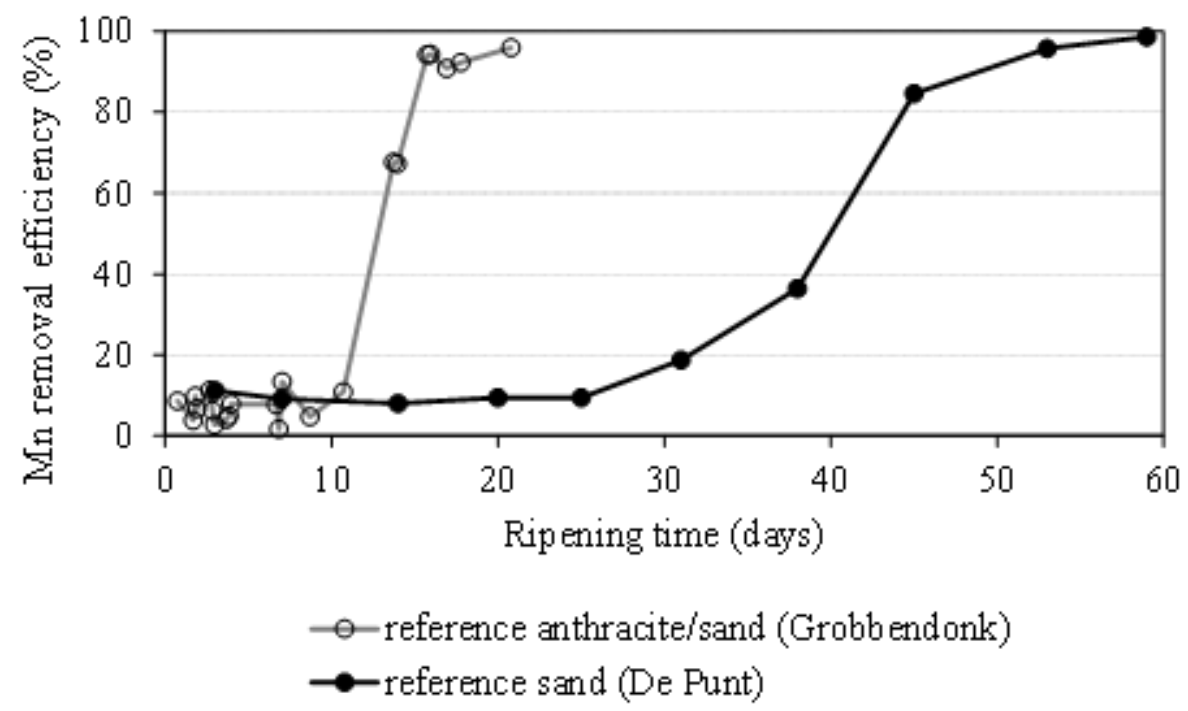

Figure 2: Comparison of the Mn removal efficiency (\%) as a function of the filter ripening time for the two reference full scale filters: (virgin) anthracite/sand, at GWTP Grobbendonk (pH: 7.5 to7.6; redox potential: +200 to $+300 \mathrm{mV}$; filtration rate: $5.0 \mathrm{~m}^{3} / \mathrm{m}^{2} . h$ ) and (virgin) sand, at GWTP De Punt (pH: 7.3 to 7.5 ; redox potential: -50 to $+50 \mathrm{mV}$; filtration rate: $4.8 \mathrm{~m}^{3} / \mathrm{m}^{2} . h$ ).

As seen from Figure 2, the ripening time required to reach $>90 \%$ manganese removal of the single media reference filter at GWTP De Punt was about 3.5 times longer (55 days) than that of the dual media reference filter at GWTP Grobbendonk (16 days). The observed difference was attributed to both the different feed water quality and the difference in applied operational conditions (e.g., backwashing pattern, intensity and frequency).

\section{Effect of water quality parameters}


It has been reported that ferrous iron competes with $\mathrm{Mn}^{2+}$ for adsorption sites on filter media (Hu et al. 2004a, b). Feed water at GWTP De Punt had a 50 to 150 times higher $\mathrm{Fe}^{2+}$ concentration than the GWTP Grobbendonk feed (Table A1). At GWTP De Punt (in combination with slightly lower feed water $\mathrm{pH}$ ), the high $\mathrm{Fe}^{2+}$ concentration caused a more pronounced competition for available adsorption sites by $\mathrm{Mn}^{2+}$. It has been reported that the presence of iron hydro-oxide layers in the filter media coating could support the $\mathrm{Mn}^{2+}$ adsorption (Buamah 2009). However iron hydro-oxide has a much lower $\mathrm{Mn}^{2+}$ adsorption capacity than manganese (hydro-) oxides (Buamah et al. 2008). Therefore formation of iron hydro-oxide layers in the filter bed zone where manganese is removed should be prevented in practice.

The feed water concentration of $\mathrm{Fe}^{2+}$ also determines an important operational condition for manganese removal, i.e., iron loading per filter run. Feed water at GWTP De Punt contained a significantly higher $\mathrm{Fe}^{2+}$ concentration, resulting in much higher iron loading per filter run than at GWTP Grobbendonk ( 2.5 and $<0.1 \mathrm{~kg} \mathrm{Fe} / \mathrm{m}^{2}$, respectively). In addition, this much higher iron loading at GWTP De Punt required an approximately 4 times more frequent backwashing than at GWTP Grobbendonk. Backwashing results in a partial removal of $\mathrm{MnO}_{\mathrm{x}}$ from the coating, while the presence of $\mathrm{MnO}_{\mathrm{x}}$ is essential for an effective manganese removal. Intensive backwashing can also cause a substantial removal of the biological activity (e.g., by removal of bacteria from filter media), which may play an important role in the process of manganese adsorption and oxidation (Vandenabeele et al. 1992; Katsoyiannis \& Zouboulis 2004; Tebo et al. 2004). Partial loss of $\mathrm{MnO}_{\mathrm{x}}$ and biological activity is even more pronounced for backwashing with combined water and air flushing. Both the frequency and intensity of the backwashing at GWTP De Punt were more detrimental for the filter media, resulting in a longer ripening time of the filters at this location.

Another water quality parameter playing an important role in manganese removal is the $\mathrm{pH}$. To achieve an effective manganese removal the $\mathrm{pH}$ should preferably be above 7.1 (Bruins et al. 2013). In general, the higher the $\mathrm{pH}$, the better the manganese removal. From the $\mathrm{pH}$ values of feed water at 
both GWTPs it can be concluded that Grobbendonk water ( $\mathrm{pH} 7.5-7.6)$ provided slightly better conditions for an effective manganese removal than GWTP De Punt water (pH 7.3 - 7.5).

$\mathrm{NH}_{4}{ }^{+}$removal efficiency is another parameter that shows a strong positive correlation with manganese removal (Bruins et al. 2013). The presence of $\mathrm{NO}_{2}^{-}$(due to incomplete $\mathrm{NH}_{4}{ }^{+}$removal) may not only prevent effective $\mathrm{Mn}^{2+}$ removal, but may even cause manganese leaching, by reducing already adsorbed and oxidised $\mathrm{MnO}_{\mathrm{x}}$ back to $\mathrm{Mn}^{2+}$ (Vandenabeele et al. 1995). The $\mathrm{NH}_{4}{ }^{+}$concentration in the filtrate of the two filters at GWTP De Punt was substantially higher than at GWTP Grobbendonk especially during the filter start-up, which could explain the much longer ripening time of filters at the De Punt location.

Finally, oxidation of (adsorbed) manganese takes place more easily at a higher redox potential (Stumm \& Morgan 1996; Scherer \& Wichmann 2000; Flemming et al. 2004). The redox potential of the feed water at GWTP De Punt was much lower compared to that of the feed water at GWTP Grobbendonk $\left(-50 /+50 \mathrm{mV}\right.$ and $+200 /+300 \mathrm{mV}$, respectively), partly caused by the presence of $\mathrm{NH}_{4}{ }^{+}$in the filtrate, which was much higher at the De Punt location. As a consequence, even if $\mathrm{Mn}^{2+}$ was adsorbed it was not as effectively oxidised and therefore possibly desorbed, resulting in a longer ripening time at the De Punt location.

Although the feed water quality at both locations is suitable to achieve effective manganese removal in a conventional aeration-filtration system once the filters are ripened, the conditions to achieve shorter filter ripening times were found to be more favourable at the Grobbendonk location.

In summary, much faster ripening of virgin filter media with respect to complete manganese removal at GWTP Grobbendonk can be attributed to the combined effect of the following parameters crucial for manganese removal:

a. more favourable feed water quality (lower $\mathrm{Fe}^{2+}$ and $\mathrm{NH}_{4}{ }^{+}$concentrations, higher $\mathrm{pH}$ and redox potential). 
b. more favourable operational conditions (lower iron loading per filter run, lower backwash frequency and intensity).

\section{MOCS and MOCA characterisation and batch adsorption experiments}

Table A4 (Annex A) depicts the physical characteristics of MOCS, MOCA, and Aquamandix (AQM), and coating composition of MOCS and MOCA.

From Table A4 (Annex A) it can be seen that the grain size of MOCA is considerably smaller than that of MOCS. As a consequence, MOCA has a larger geometric surface area, enhancing the adsorption capacity. Another characteristic indicating a better adsorption capacity of MOCA is the coating composition. The most pronounced difference in chemical composition of the two media is the iron content. Iron is present as iron (hydr)oxide, whereas manganese is present as manganese oxide $\left(\mathrm{MnO}_{\mathrm{x}}\right)$. Although both oxides can absorb $\mathrm{Mn}^{2+}$, iron (hydr)oxide has a significantly lower manganese adsorption capacity (Buamah et al. 2008). Therefore it was expected that MOCA with a more than 70 times lower iron content, would adsorb $\mathrm{Mn}^{2+}$ better. On the other hand the $p H_{P Z C}$ of MOCS was significantly lower compared to MOCA. This suggests that MOCS will have better adsorptive properties over a wider $\mathrm{pH}$ range for positively charged ions such as $\mathrm{Mn}^{2+}$.

In Table 1 the Freundlich adsorption isotherm constants for manganese adsorption on MOCS, MOCA, and Aquamandix are given.

Table 1: Freundlich adsorption isotherm constants for $\mathrm{Mn}^{2+}$ adsorption on MOCS, MOCA and Aquamandix.

\begin{tabular}{|c|c|c|c|}
\hline \multirow{2}{*}{ Constant } & \multicolumn{3}{|c|}{ Adsorbent } \\
\cline { 2 - 4 } & MOCS & MOCA & Aquamandix \\
\hline$K[(\mathrm{mg} / \mathrm{g}) /(\mathrm{mg} / \mathrm{L})]$ & 0.45 & 0.91 & 0.90 \\
\hline $1 / n$ & 1.31 & 1.34 & 1.38 \\
\hline $\mathrm{r}^{2}$ & 0.91 & 0.91 & 0.96 \\
\hline
\end{tabular}




\begin{tabular}{|c|c|c|c|}
\hline$q_{e}(\mathrm{mg} / \mathrm{g})$ & 0.132 & 0.276 & 0.280 \\
at $C_{e}=0.2 \mathrm{mg} / \mathrm{L}$ & & & \\
\hline$q_{e}(\mathrm{~g} / \mathrm{L})$ & 0.155 & 0.179 & 0.560 \\
at $C_{e}=0.2 \mathrm{mg} / \mathrm{L}$ & & & \\
\hline
\end{tabular}

From Table 1 it can be seen that manganese adsorption capacities, $q_{e}$ expressed per unit weight of adsorbent, for MOCS and MOCA are very different $\left(0.132\right.$ and $0.276 \mathrm{mg} / \mathrm{g}$ ads., respectively, at $C_{e}$ of $0.2 \mathrm{mg} / \mathrm{L} \mathrm{Mn}^{2+}$ ). When expressed per unit volume, however, adsorptive capacities of MOCS and MOCA were found to be similar $\left(0.155\right.$ and $0.179 \mathrm{mg} \mathrm{Mn}^{2+} / \mathrm{L}$ of MOCS and MOCA, respectively, at $C_{e}$ of $0.2 \mathrm{mg} \mathrm{Mn}{ }^{2+} / \mathrm{L}$ ). A much higher adsorption capacity per volume of adsorbent was found for Aquamandix. However this commercial adsorbent has no auto-catalytic oxidation properties, thus once the adsorption capacity is exhausted, manganese removal stops (Buamah 2009).

Based on the adsorption capacities, $q_{e}$, reported in Table 1, the (calculated) theoretical manganese adsorption capacities of the MOCS and MOCA layers, placed in the full scale test filters are calculated (Table A5). This table also shows the expected operational times of the filters before manganese breakthrough, assuming that adsorption was the only manganese removal mechanism ignoring the catalytic effect associated with adsorption and oxidation of adsorbed manganese. For a $15 \mathrm{~cm}$ MOCS layer (De Punt), the $\mathrm{Mn}^{2+}$ adsorption capacity is approximately $0.29 \mathrm{~kg}$, with an expected breakthrough after 24 to $48 \mathrm{hrs}$, whereas these values for a $10 \mathrm{~cm}$ layer of MOCA (Grobbendonk) are respectively $0.67 \mathrm{~kg} \mathrm{Mn}^{2+}$ and breakthrough also after 24 to $48 \mathrm{hrs}$.

\section{Ripening of full scale filters with the addition of MOCS and MOCA layers}

Manganese removal during the ripening time of the two full scale filters at GWTP De Punt are shown in Fig. 3(L). Based on batch adsorption experiments conducted with fresh MOCS (Tables 1 and A5), it was expected that the MOCS layer in the full scale filter would effectively remove $\mathrm{Mn}^{2+}$ at least during the first $24-48$ hrs. However, the addition of $15 \mathrm{~cm}$ of MOCS did not have a significant impact on the ripening time of the filter with respect to the manganese removal. The reason for the poor $\mathrm{Mn}^{2+}$ 
removal is probably attributed to the difference in adsorptive properties of MOCS used in the batch adsorption experiments (freshly taken from a running ripened filter), and in the filter runs (dried and stored for several months before use). The layered structure of Birnessite may have irreversibly collapsed, decreasing the number of available adsorptive sites (Post 1999). Furthermore, long exposure to air may have resulted in (complete) oxidation of the auto-catalytically active Birnessite into not auto-catalytically active Pyrolusite $\left(\mathrm{MnO}_{2}\right)$. Storage of the MOCS could also have resulted in a loss of biological activity (e.g., by dying of bacteria present on MOCS), which may play an important role in initiating oxidation of manganese adsorbed on filter media (Vandenabeele et al. 1992; Katsoyiannis \& Zouboulis 2004; Tebo et al. 2004). Drying and storage of the MOCS used in the full scale filter most likely caused loss of a substantial part of its original adsorption capacity. Besides, it is most likely the stored MOCS had lost its auto-catalytic and biological activity.
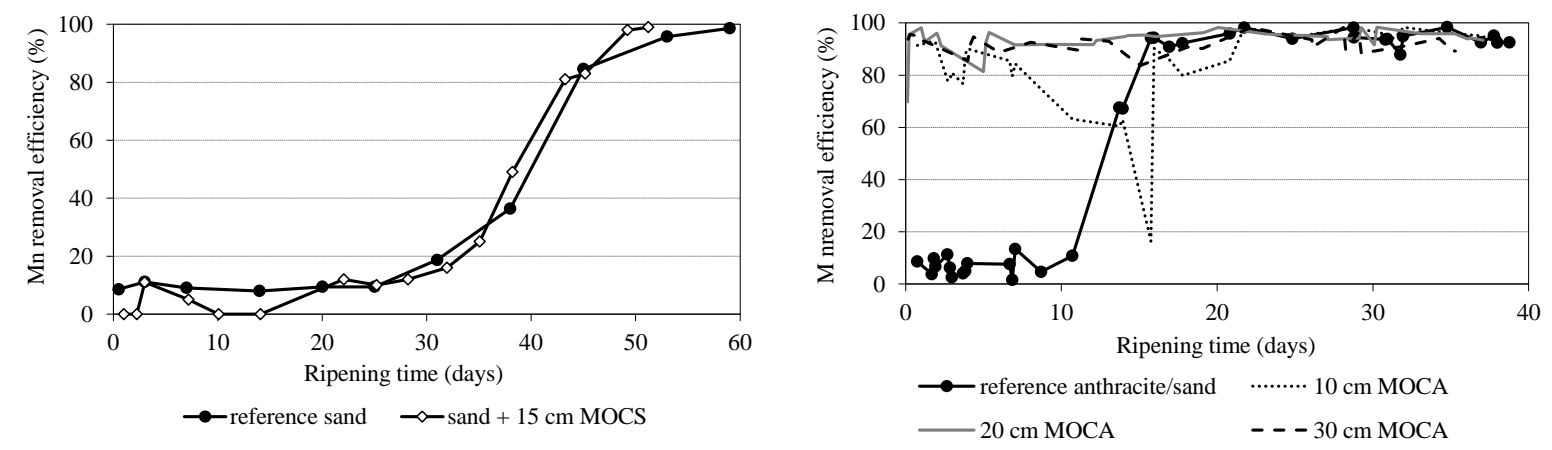

Figure 3: Mn removal efficiency (\%) as a function of the ripening time of two (full scale) test filters at GWTP De Punt (L) - (pH: 7.3 to 7.5; redox potential: -50 to $+50 \mathrm{mV}$; filtration rate: $4.8 \mathrm{~m}^{3} / \mathrm{m}^{2} . h$ ) and four full scale test filters at GWTP Grobbendonk $(R)$ - (pH: 7.5 to7.6; redox potential: +200 to $+300 \mathrm{mV}$; filtration rate: 5.0 $\left.m^{3} / m^{2} \cdot h\right)$

In Fig. 3(R) the results of the experiments with four full scale test filters at GWTP Grobbendonk are shown. At this location the filter ripening time of the reference anthracite/sand filter was compared to the ripening times of three test filters containing MOCA layers of different thicknesses (Figs. $1^{\mathrm{D}-\mathrm{F}}$ ). Results obtained with the test filters containing a layer of MOCA showed a very high (>90\%) manganese removal from the start of the filter run, irrespective of the thickness of the MOCA layer. 
As a comparison, the manganese removal efficiency in the reference filter without a MOCA layer was approximately $10 \%$ during the first 10 days of operation.

Assuming that the manganese removal in the test filters was achieved only by adsorption on MOCA, the filter with a $10 \mathrm{~cm}$ layer should display breakthrough after $24 \mathrm{hrs}$ of filter operation (Table A5, Annex A). However, no breakthrough was observed during more than a month of continuous operation of the test filters, most likely due to the presence of Birnessite and/or manganese oxidising bacteria in the fresh MOCA, promoting autocatalytic oxidation, resulting in the immediate formation of a new active $\mathrm{MnO}_{\mathrm{x}}$ layer.

After about 2.5 days and in particular after 15 days of operation, a decrease in manganese removal efficiency was observed for the test filter with a $10 \mathrm{~cm}$ layer of MOCS. The reason was an operational malfunctioning, caused by a poor distribution of the feed water over the filter surface. Additionally, the feed water jet disrupted the top of the MOCA layer, locally thinning the layer to less than $10 \mathrm{~cm}$. As soon as the MOCA layer was restored by a gentle backwash, manganese removal efficiency was re-established.

Based on the results depicted in Fig. 3(R), a $10 \mathrm{~cm}$ layer of fresh MOCA is sufficient to achieve an efficient manganese removal from the start of a new filter. However, to prevent practical problems (e.g., short circuiting), it is recommended to apply a MOCA layer of at least $20 \mathrm{~cm}$ thickness.

Comparing the results of the full scale test filters with an added MOCS (Fig. $1^{\mathrm{B}}$ ) and MOCA layer (Fig. $1^{\text {D-F }}$ ), a poor ripening of filters containing MOCS and a fast ripening of filters containing MOCA was observed. The major reason for the poor results achieved with the MOCS layer in a filter was probably, as explained above, attributed to the use of aged (dried) MOCS. The difference in performance could also be caused by the different feed water quality (e.g., redox potential, $\mathrm{NH}_{4}{ }^{+}$ removal, $\mathrm{pH}$ ), difference in MOCS and MOCA composition (coating Fe content) and different 
operational conditions applied (grain size of MOCS is approximately double that of MOCA, and $\mathrm{Fe}^{2+}$ loading and backwashing pattern and frequency were significantly different).

To summarise, this research showed that fresh manganese oxide-coated filter media were able to shorten the filter media ripening time substantially. Drying the MOCS has affected the results dramatically. In addition differences may have been caused by water quality as well as operational conditions. These phenomena must be investigated in more detail under comparable conditions, emphasising also the role of micro-biology and the importance and influence of specific bacteria.

\section{CONCLUSIONS}

The ripening time required to achieve complete manganese removal with (reference) full scale filters with virgin sand and virgin anthracite/sand filter media at two GWTPs; De Punt (The Netherlands) and Grobbendonk (Belgium) was found to be 55 and 16 days, respectively.

Differences in duration of ripening times between filters of the two GWTPs is caused by a combination of factors including the different composition of feed water $(\mathrm{pH}$, redox potential, concentration of $\mathrm{Fe}^{2+}$ and $\mathrm{NH}_{4}^{+}$), applied process design and operational conditions (e.g., iron load, intensity and frequency of backwashing and physical properties and composition of virgin filter media).

Batch adsorption experiments demonstrated that both (fresh) MOCS and (fresh) MOCA adsorb $\mathrm{Mn}^{2+}$. Based on Freundlich adsorption isotherm measurements, the manganese adsorption capacity $\left(q_{e}\right)$ expressed per unit weight of adsorbent of MOCA was approximately twice the capacity of MOCS. However, when expressed per unit volume of adsorbent, which is more relevant for a practical application, the manganese adsorption capacities of MOCA and MOCS were similar. The adsorption capacity of commercial manganese adsorbent (Aquamandix), expressed per unit volume, was found to be approximately 3 times higher. 
Aging and drying of MOCS, most probably resulted in the loss of manganese adsorption capacity. Besides, drying of MOCS may have caused the loss of auto-catalytic activity by changes in its structure and complete manganese oxidation. Finally the biological activity may have been lost.

The ripening time of a full scale filter with virgin anthracite/sand filter media, before reaching an effective manganese removal at GWTP Grobbendonk, of typically 16 days could be eliminated when a 0.10 to $0.30 \mathrm{~m}$ deep layer of fresh MOCA is placed on top of the virgin anthracite/sand filter bed. Because of operational aspects, it is advisable to apply a MOCA layer with a thickness $\geq 0.2 \mathrm{~m}$.

In a follow up research, based on the results obtained from this study, the effect of water quality and operational conditions, as well as the role of micro-biology on filter media ripening, will be investigated in more detail under comparable conditions.

\section{ACKNOWLEDGEMENTS}

This research is financially and technically supported by WLN and the Dutch water companies Waterbedrijf Groningen and Waterleiding Maatschappij Drenthe. The authors would like to thank Mr A.A.S. Al Abri (MSc graduate at UNESCO-IHE) for his contribution to this work. Thanks also to the Belgian water company Pidpa, for providing a full scale test location Grobbendonk and their willingness to share the data from their groundwater treatment plant.

\section{REFERENCES}

Appelo, C.A.J. \& Postma, D. 2005 Geochemistry, groundwater and pollution, $2^{\text {nd }}$ edition, CRC press, Boca Raton (FL), USA.

Bruins, J.H., Petrusevski, B., Slokar, Y.M., Kruithof, J.C. \& Kennedy, M.D. 2014 Manganese removal from groundwater: characterization of filter media coating. Desalination and Water Treatment, in press. 
Bruins, J.H., Vries, D., Petrusevski, B., Slokar, Y.M. \& Kennedy, M.D. 2013 Assessment of manganese removal from over 100 groundwater treatment plants. Journal of Water Supply: Research and Technology-AQUA, 63(4), 268-280.

Buamah, R. 2009 Adsorptive removal of manganese, arsenic and iron from groundwater. PhD thesis, University Wageningen and UNESCO-IHE Delft, The Netherlands, ISBN 978-0-415-57379-5.

Buamah, R., Petrusevski B., de Ridder, D., van de Watering, T.S.C.M. \& Schippers, J.C. 2009a Manganese removal in groundwater treatment: practice, problems and probable solutions. Water Science and Technology: Water Supply, 9(1), 89-98.

Buamah, R., Petrusevski, B. \& Schippers, J.C. 2008 Adsorptive removal of manganese (II) from the aqueous phase using iron oxide coated sand. Journal of Water Supply: Research and Technology-AQUA, 57(1), 1-11.

Burger, M.S., Mercer, S.S., Shupe, G.D. \& Gagnon, G.A. 2008 Manganese removal during benchscale biofiltration. Water Research, 42, 4733-4742.

Cools, B. 2010 Vlaamse Maatschappij voor Watervoorziening (VMW), Belgium. Personal communication.

Diem, D. \& Stumm W. 1984 Is dissolved $\mathrm{Mn}^{2+}$ being oxidized by $\mathrm{O}_{2}$ in absence of Mn-bacteria or surface catalysts. Geochimica et Cosmochimica, 48, 1571-1573

Fiol, N. \& Villaescusa, I. 2009 Determination of sorbent point zero charge: usefulness in sorption studies. Environmental Chemistry Letters, 7, 79-84.

Flemming, H.C., Steele, H., Rott, U. \& Meyer, C. 2004 Optimirung der in-situ reaktortechnologie zur dezentralen trinkwassergewinnung und grundwasseraufbereitung durch modelhafte untersuchungen beteiligter biofilme. Report by the Institute for Sanitary Engineering, Water Quality and Solid Waste Management of the University of Stuttgart.

Hu, P-Y., Hsieh, Y-H., Chen, J-C. \& Chang, C-Y. 2004a Adsorption of divalent manganese ion on manganese coated sand. Journal of Water supply: Research and Technology - AQUA, 53(3), $151-158$.

Hu, P-Y., Hsieh, Y-H., Chen, J-C. \& Chang, C-Y. 2004b Characteristics of manganese-coated sand using SEM and EDAX analysis. Journal of Colloid and Interface Science, 272, 308-313. 
Katsoyiannis, I.A., Zikoudi, A. \& Hug, S.J. 2008 Arsenic removal from groundwaters containing iron, ammonium, manganese and phosphate: A case study from a treatment unit in northern Greece. Desalination, 224, 330-339.

Katsoyiannis, I.A. \& Zouboulis, A.I. 2004 Biological treatment of Mn(II) and Fe(II) containing groundwater: kinetic considerations and product characterization. Water Research, 38, 19221932.

Kim, J. \& S. Jung 2008 Soluble manganese removal by porous media filtration. Environmental Technology, 29(12), 1265-1273.

Kim, W.G., Kim, S.J., Lee, S.M. \& Tiwari, D. 2009 Removal characteristics of manganese-coated solid samples for Mn(II). Desalination and Water Treatment, 4, 218-223.

Knocke, W.R., Van Benschoten, J.E., Kearny, M.J., Soborski, A.W. \& Reckhow, D.A. 1991 Kinetics of manganese and iron oxidation by potassium permanganate and chlorine dioxide. Journal of $A W W A$, June, 80-87.

Krull, J. 2010 Stadtwerke Emden (SWE), Germany. Personal communication.

NEN 2004 Water quality - Application of inductively coupled plasma mass spectrometry (ICP-MS) Part 2: Determination of 62 elements, NEN-EN-ISO 17294-2.

Post, J.E. 1999 Manganese oxide minerals: Crystal structures and economic and environmental significance. Proceedings of the National Academy of Sciences USA, 96, 3447-3454.

Sahabi, D.M., Takeda, M., Suzuki, I. \& Koizumi, J-I. 2009 Removal of $\mathrm{Mn}^{2+}$ from water by "aged" biofilter media: The role of catalytic oxides layers. Journal of Bioscience and Bioengineering, 107(2), 151-157.

Scherer, E. \& Wichmann, K. 2000 Treatment of groundwater containing methane - combination of the processing stages desorption and filtration. Acta Hydrochemica et Hydrobiologica, 28(3), 145154

Stumm, W. \& Morgan, J.J. 1996 Aquatic Chemistry, Chemical Equilibria and Rates, $3^{\text {rd }}$ edition, Wiley, New York. 
Tebo, B.M., Marger, J.R., Clement, B.G., Dick, G.J., Murray, K.J., Parker, D., Verity, R. \& Webb, S.M. 2004 Biogenic manganese oxides: Properties and mechanisms of formation. Annual Review of Earth and Planetary Sciences, 32, 287-328.

UNEP 2008 Vital water graphics. Available at http://www.unep.org/dewa/vitalwater/index.html.

Vandenabeele, J., De Beer, D., Germonpré, R. \& Verstreate, W. 1992 Manganese oxidation by microbial consortia from sand filters. Microbial Ecology, 24, 91-108.

Vandenabeele, J., Van de Woestyne, M., Houwen, F., Germonpré, R., Vandesande, D. \&Verstreate, W. 1995 Role of autotrophic nitrifiers in biological manganese removal from groundwater containing manganese an ammonium. Microbial Ecology, 28, 83-98.

First received 27 August 2014; accepted in revised form 17 December 2014. Available online 


\section{ANNEX A FIGURES AND TABLES}

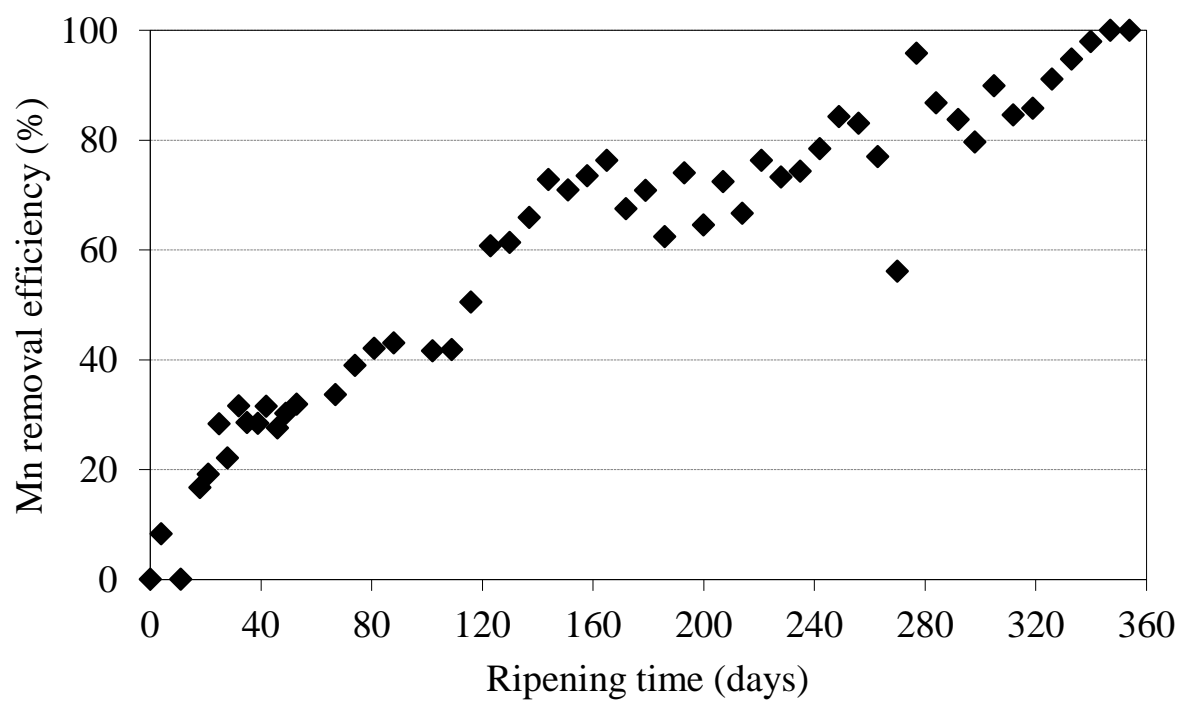

Figure A1: An example of a very long ripening time of virgin filter media for manganese removal in a Dutch full scale groundwater treatment plant (GWTP Baanhoek, Evides Water Company).

Table A1: Composition of feed water during the experiments with full scale filters.

\begin{tabular}{|l|c|c|c|}
\hline Parameter & Unit & De Punt & Grobbendonk \\
\hline \hline Iron & $\mathrm{mg} / \mathrm{L}$ & $4.5-6.9$ & $0.03-0.14$ \\
\hline Manganese & $\mathrm{mg} / \mathrm{L}$ & $0.18-0.25$ & $0.12-0.18$ \\
\hline Ammonium & $\mathrm{mg} / \mathrm{L}$ & $0.29-0.78$ & $<0.05-0.23$ \\
\hline $\mathrm{pH}$ & {$[-]$} & $7.3-7.5$ & $7.5-7.6$ \\
\hline Oxygen & $\mathrm{mg} / \mathrm{L}$ & $8-10$ & $>10$ \\
\hline Redox potential & $\mathrm{mV}$ & -50 to +50 & +200 to +300 \\
\hline
\end{tabular}

Table A2: Process design parameters and operational conditions of full scale manganese removal experiments at GWTP De Punt and GWTP Grobbendonk.

\begin{tabular}{|l|c|c|c|}
\hline Parameter / condition & Unit & De Punt & Grobbendonk \\
\hline \hline Type of aeration & - & spray & cascade \\
\hline
\end{tabular}




\begin{tabular}{|c|c|c|c|}
\hline Position of filter & - & 'pre-filter' & 'post-filter' \\
\hline Type of filtration & - & down flow & down flow \\
\hline Type of filter media & - & quartz sand & anthracite / quartz sand \\
\hline Grain size fraction virgin media & $\mathrm{mm}$ & $1.8-2.4$ & $0.8-1.8 / 0.4-0.8$ \\
\hline Filter area & $\mathrm{m}^{2}$ & 12.5 & 37.5 \\
\hline Filter bed height & $\mathrm{m}$ & 2 & $1.1(0.6+0.5)$ \\
\hline Flow per filter & $\mathrm{m}^{3} / \mathrm{h}$ & 60 & 190 \\
\hline Filtration rate & $\mathrm{m}^{3} / \mathrm{m}^{2} \cdot \mathrm{h}$ & 4.8 & 5.0 \\
\hline Empty bed contact time & $\min$ & 25 & 13.2 \\
\hline Backwash (BW) criterion & - & head loss & head loss \\
\hline Backwash frequency & n/week & 2 & 0.5 \\
\hline Filter bed expansion during BW & - & no & yes (anthracite) \\
\hline Filtered volume between BW & $\mathrm{m}^{3}$ per filter run & $5,000-7,000$ & 10,000 \\
\hline Iron loading per filter run (FR) & $\mathrm{kg} \mathrm{Fe} / \mathrm{m}^{2} . \mathrm{FR}$ & 2.5 & $<0.1$ \\
\hline
\end{tabular}

Table A3: Backwash procedures applied at full scale plants De Punt and Grobbendonk.

\begin{tabular}{|c|c|c|c|c|c|}
\hline \multicolumn{3}{|c|}{ GWTP De Punt } & \multicolumn{3}{|c|}{ GWTP Grobbendonk } \\
\hline \multicolumn{2}{|c|}{$V_{f}\left(\mathrm{~m}^{3} / \mathrm{m}^{2} \cdot \mathrm{h}\right)$} & Duration & \multicolumn{2}{|c|}{$V_{f}\left(\mathrm{~m}^{3} / \mathrm{m}^{2} \cdot \mathrm{h}\right)$} & Duration \\
\hline Water & Air & Minutes & Water & Air & Minutes \\
\hline- & 24 & 1 & 10.6 & - & 0.33 \\
\hline- & 52 & 5 & - & 60 & 1 \\
\hline 13.6 & 28 & 3 & 23.8 & - & 5 \\
\hline 24 & 28 & 5 & - & - & - \\
\hline 24 & - & 8 & - & - & - \\
\hline 13.6 & - & 3 & - & - & - \\
\hline
\end{tabular}


Table A4: Physical characteristics of MOCS, MOCA and AQM, and the coating composition of MOCS and MOCA.

\begin{tabular}{|c|c|c|c|c|c|}
\hline & Parameter & Unit & MOCS & MOCA & $\mathrm{AQM}^{*}$ \\
\hline \multirow{6}{*}{ 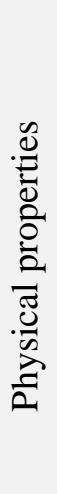 } & Bulk density & $\mathrm{kg} / \mathrm{L}$ & 1.177 & 0.650 & 2.000 \\
\hline & Particle density & $\mathrm{kg} / \mathrm{L}$ & 2.326 & 1.176 & 3.600 \\
\hline & Porosity & $\%$ & 49.4 & 44.7 & 44.4 \\
\hline & Grain size $\left(d_{10^{-}} d_{90}\right)$ & $\mathrm{mm}$ & $1.6-3.1$ & $0.8-1.5$ & $1.0-2.0$ \\
\hline & Uniformity coefficient & {$[-]$} & 1.58 & 1.52 & - \\
\hline & $p H_{P Z C}$ & {$[-]$} & 7.2 & 8.0 & 5.0 \\
\hline \multirow{5}{*}{ 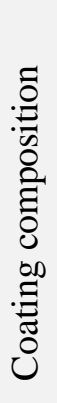 } & $\mathrm{Mn}$ & $\mathrm{mg} / \mathrm{g}$ & 12.8 & 13.5 & - \\
\hline & $\mathrm{Fe}$ & $\mathrm{mg} / \mathrm{g}$ & 158 & 2.22 & - \\
\hline & $\mathrm{Ca}$ & $\mathrm{mg} / \mathrm{g}$ & 8.85 & 2.45 & - \\
\hline & $\mathrm{Si}$ & $\mathrm{mg} / \mathrm{g}$ & 14.5 & 0.28 & - \\
\hline & $\mathrm{Al}$ & $\mathrm{mg} / \mathrm{g}$ & 0.47 & 0.25 & - \\
\hline
\end{tabular}

* According to the supplier, Aquamandix consists of $78 \% \mathrm{MnO}_{2}, 6.2 \% \mathrm{Fe}_{2} \mathrm{O}_{3}, 5.2 \% \mathrm{SiO}_{2}, 3.1 \% \mathrm{Al}_{2} \mathrm{O}_{3}$.

Table A5: Calculated theoretical adsorptive capacity of MOCS and MOCA layers with associated duration of filter run (FR) time before the manganese breakthrough.

\begin{tabular}{|l|l|c|c|}
\hline Filter & Filter bed media & Capacity $^{1}$ & FR time before Mn \\
& & $(\mathrm{kg})$ & breakthrough $^{2}$ \\
& & & \\
\hline A & reference sand & \\
\hline B & sand +15 cm MOCS & 0 & - \\
\hline C & reference anthracite/sand & 0.29 & -48 \\
\hline D & anthracite/sand $+10 \mathrm{~cm} \mathrm{MOCA}$ & 0.67 & $24-48$ \\
\hline E & anthracite/sand $+20 \mathrm{~cm}$ MOCA & 1.34 & $48-96$ \\
\hline
\end{tabular}




\begin{tabular}{|l|l|l|l|}
\hline F & anthracite/sand $+30 \mathrm{~cm}$ MOCA & 2.01 & $72-144$ \\
\hline
\end{tabular}

${ }^{1}$ At $C_{e}=0.2 \mathrm{mg} / \mathrm{L}$

${ }^{2}$ For $V_{f}$ between $2.5-5 \mathrm{~m}^{3} / \mathrm{m}^{2} . h$ 